\title{
The Combined Effect of Water-logging and Salinity on Crops Yield
}

\author{
Walaa Y. El-Nashar ${ }^{1}$ \\ ${ }^{I}$ (Water Engineering and Water Structure Engineering Department, Faculty of Engineering, Zagazig University, \\ Zagazig, Egypt)
}

\begin{abstract}
Water-logging and salinization continue to cause economic losses in many areas of the world, though farmers and scientists have been aware of these problems and potential technical solutions for thousands of years. In this research a model is suggested to study the effect of water-logging on the net profit from the crops farm yield. The duration of water-logging according to different irrigation systems, crop type and soil type by calculating water consumptive use for each crop using Blaney-Criddle method and calculating the amount of deep percolation that causes water table rising, the effect of salinity on crops yield only, the combined effect of water-logging and salinity on crops yield. This research includes application of this model in El-Salhia, Egypt to estimate maximum profits according combined effect of water-logging and salinity on the crops yield.
\end{abstract}

Key words: Water-logging, Consumptive Use, Salinity, Crop Yield, Egypt.

\section{Introduction}

Water-logging and salinity problems often require some form of drainage to allow sustainable agriculture production. This must be an integral part of irrigation system investments. However, poor irrigation and agronomic practices have led salinity and water logging, thus there are many researches in this branch such as Barrett L et al [1] described a method for the establishment of controlled water-logging events in the field. Wichelns D. [2] examined farm-level and project-level models of crop production to identify policies that will encourage farmers to consider opportunity costs and the effects of irrigation and leaching on depth to regional water tables. Kotob T.et al [3] described counter-measures taken by the government on a national and regional scale and farmers on a local or field scale. McFarlane D and Williamson D [4] identified three types of water logging. These were associated with perched aquifers in texture contrast soils, inundation of terraces and valleys, and saturation in surface soil due to the hydraulic pressure being above ground level in aquifers at the base of the regolith of highly weathered granites and gneisses or within channels in broad valley sediments. Pereira L., Oweis T. and Zairi A. [5] proposed some concepts relative to water scarcity, concerning aridity, drought, desertification and water shortage, as well as policies to cope with these water stressed regimes. Hatton T. et al [6] studied water-logging and groundwater recharge at a site in southwestern Australia characterized by sloping duplex soils in a Mediterranean environment. Silberstein R. et al Bartle [7] studied the occurrence of seasonal water logging across a small catchment in the south-west of Western Australia. Barrett-Lennard E. [8] reviewed a range of studies under controlled conditions focusing on the effects of the interaction between waterlogging and salinity on the ion relations, growth and survival of higher plants. Turner N. [9] made an analysis of the yield increases of wheat in Mediterranean- climatic regions which showed that there had generally been an increase in the yields over the past decades, albeit at a lower rate than in more temperate regions. Cornelious B. et al [10] identified quantitative trait loci that condition water-logging tolerance in soybean. Su-qin H.et al [11] analyzed the risk of urban rainstorm water-logging facing the Tianjin city through methods of probability, investigation and statistics, and numerical simulation. Jacob W. [12] examined that why salinity of soil and irrigation water was common and nearly inevitable in the irrigated lands of the semi-arid tropics and subtropics. Choudhury N. [13] studied to map the performance of different canal irrigation systems in terms of quality of irrigation services delivered, as perceived by the farmers. Elew H., and ElNahry A. [14] collected eight water samples from ground-water monitoring wells and 13 water samples from surface water, and analyzed for various hydro-chemical parameters. Prietzel J., Thieme J., and Paterson D. [15] analyzed the phosphorus speciation of organic surface layers from two adjacent German forest soils with different degree of waterlogging. El-Bastawesy M. and Ali R. [16] investigated the interplay of the hydro-geological characteristics, soil properties and recent land reclamation projects on the distribution of water-logging and salinization within the Farafra Oasis. Guang C. et al [17] studied the problem of cotton suffering from waterlogged stress on cotton leaf yield, in rainy and humidity region of south China. Rizvi F. [18] looked into the instances of growing waterlogging, which was a negative externality of the developmental process. Magsi H. and Torre A. [19] used the Chotiari water reservoir project data from Pakistan, to explore the social network of actors on land used and propertied right violation, which created a dissimilar power distribution and significant lands used conflicts. 
Badiani R., Jessoe K. and Plant S. [20] provided an overview of subsidies in India, detailing the rationale behind their introduction and their evolution over time. Xiugui W. et al [21] studied the Morgan model to simulate cotton response to water-logging stress in south China. Saqib M. et al [22] screened and characterized wheat genotypes for performance under salt stress and/or water-logging.

The main objective of this study is estimating a model of the net profit from the farm according to the effect of both water-logging and salinity on different crops yield. The duration of water logging is calculated also according to crop type, soil type and irrigation method. This model is applied in ElSalhia, Egypt as a case study.

\subsection{Methods of Measuring and Estimating Water-logging Intensity and Duration}

The measurement of water logging intensity and duration is usually confined to experimental sites though they have application in farm management. The methods applied include:

1- The determination of the intensity and duration of saturation of the root zone using shallow dip wells inserted to the top of the perching layer.

2- Examination of historical crop or pasture yields and corresponding rainfall;

3- Estimation based on knowledge of soil hydraulic properties and climate data;

4- Inference of water logging intensity from soil morphology;

5- Mapping water logging damage in crops using satellite remote sensing.

\section{Methodology}

This research suggest a model to estimate the net profit from a farm, by estimating the effect of both of water-logging and salinity on the crops yield. Estimate the effect of water-logging only on the crop yield, the duration of water-logging according to different irrigation systems, crop type and soil type by calculating water consumptive use for each crop using Blaney-Criddle method and calculating the amount of deep percolation that causes water table rising, the effect of salinity on crops yield only, the combined effect of water-logging and salinity on crops yield. This model is applied in El-Salhia, Egypt as a case study.

\section{Farm Model}

The farm model irrigation objective can be described as maximizing the present value of the net profit. Farmers in arid areas must apply supplemental water for irrigation and leaching to satisfy crop water requirements and prevent salt accumulation in the root zone. Both irrigation and leaching add salt to the soil profile. In areas where downward movement of water is restricted by impervious clay layers, deep percolation can cause a rise in the height of shallow water tables. In the absence of policies that address irrigation and leaching, farmers will not have an economic incentive to consider the effects of their decisions on regional water tables.

A farmer's objective function for production of a single crop on one unit of land can be described as in Equation (1) which represents how the net profits are estimated across all crops (k), irrigated fields (i), and canal areas (A).

$$
\begin{aligned}
& \text { Net.profit }=\sum_{A=1}^{A} \sum_{i=1}^{i} \sum_{k=1}^{k}\left[\left(P_{k}-H_{k}\right) * Y_{A i k}-P_{w}\left(v_{r}+v_{l}\right)\right] \\
& Y_{A i k}=Y * Y_{W T D} * Y_{S}
\end{aligned}
$$

Where,

$\mathrm{P}_{\mathrm{k}}$ : Crop price;

$\mathrm{H}_{\mathrm{k}}$ : Crop harvest cost;

$\mathrm{Y}_{\text {Aik }}$ : The estimated yield on each canal area field for each crop;

$\mathrm{P}_{\mathrm{w}}$ : water price;

$\mathrm{V}_{\mathrm{r}}, \mathrm{V}_{\mathrm{l}}$ : are the volumes of water used for irrigation and leaching respectively;

$\mathrm{Y}_{\mathrm{WTD}}$ : The relative yield as a result of water table depth;

$\mathrm{Y}_{\mathrm{s}}$ : Relative crop yield as a result of salinity;

The model includes separate irrigation and leaching activities because farmers in arid areas often apply water specifically for leaching before crops are planted or while fields are fallow. They may also use different methods for irrigation and leaching events, and the impact of water deliveries on deep percolation may vary by technology and season. As a result, separate policy programs or parameter values may be appropriate for irrigation and leaching. The volume and quality of leaching water are included in the crop yield function because some of the water and salt applied during leaching events remain in the soil and affect plant growth. 


\subsection{Effect of Water-logging on the Crop Yield}

\section{Impact Of Water Logging}

The effect of water logging on plant growth depends on the duration of saturated conditions, the proportion of the potential root zone affected, the limitation on root elongation, the rate at which oxygen is depleted, the effect on availability and uptake of nutrients, and the accumulation of toxins. The rate of oxygen depletion, and degree of harm caused by water logging, depends upon a number of factors-temperature, availability of organic matter, salinity, acidity and the stage of growth of the plant.

There are three basic requirements for water logging to occur in the root zone of plants: (1) supply of water sufficient to produce saturation of the soil within the root zone, (2) mechanisms and physical characteristics by which water is supplied to, and retained within the root zone, (3) adequate time for saturation of the plant roots to produce anaerobic conditions and associated changes in biological and chemical activity which is detrimental to plant health.

The relationship between water table depth and crop yield can be shown mathematically in a similar manner as the relative yield concept for soil salinity. Where the relative yield as a result of water table depth $\left(\mathrm{Y}_{\mathrm{WTD}}\right)$ can be shown as follows [23]:

$\mathrm{Y}_{\mathrm{WTD}}=100-\mathrm{d}(\mathrm{c}-\mathrm{WT})$ for $0 \leq \mathrm{WT} \leq \mathrm{c}$.

Where,

d: The slope of the water logging response curve;

WT: is the depth to water table;

c: The water table depth threshold level at which crop yields begin to be affected;

The estimated thresholds and slope parameters for all of the relevant crops can be seen in Table 1 .

Table 1, Estimated Values of Water logging Thresholds and Slope Parameters.

\begin{tabular}{|l|l|l|}
\hline Crop & Threshold $(\mathrm{c}(\mathrm{m}))$ & Slop $(\mathrm{d})$ \\
\hline Beans & 1.48 & 19 \\
\hline Maize & 1.13 & 66 \\
\hline Citrus & 1.0 & 84 \\
\hline Vegetables & 0.56 & 230 \\
\hline Sugarcane & 0.96 & 110 \\
\hline Wheat & 0.85 & 36 \\
\hline
\end{tabular}

\subsection{Water-logging Duration}

In this study, the duration of water logging is calculated for six crops, three types of soil and three types of irrigation systems.

\subsubsection{Soil Classification}

Three field specimens are classified in the soil lab, Faculty of Engineering, Zagazig University, to calculate how much sand, clay, and silt, are in each specimen. The first specimen is Sand. The other two specimens are classified by washing it on sieve No.200 by water to separate sand from fines, then this sand is drying at oven at $110 \mathrm{c}^{\circ}$ along $24 \mathrm{hr}$, and weight dry sand and compute its ratio in the specimen. Use hydrometer to separate fines (silt from clay), to compute silt ratio and clay ratio. In the second specimen, the percentage of sand is $37 \%$, the ratio of clay is $38.5 \%$, the ratio of silt is $24.5 \%$, and so that this specimen is clay loam. In the third specimen the percentage of sand is zero $\%$, the ratio of clay is $69.5 \%$, and the ratio of silt is $30.5 \%$, such that the third specimen is clay.

\subsubsection{Consumptive use of Different Crops $(\mathrm{Cu})$}

By using Blaney-Criddle method [24] the $\mathrm{Cu}$ for different crops is calculated for climate of Egypt which latitude is $20^{\circ}-31.15^{\circ}$

$\mathrm{Cu}=4.57 * \mathrm{k} * \mathrm{P} *(\mathrm{t}+17.8) / 100(\mathrm{~cm} / \mathrm{month})$.

Where,

k: Crop coefficient;

$\mathrm{P}$ : the monthly percent of daytime hours;

t: Mean monthly temperature.

\subsubsection{Deep Percolation Losses According to Irrigation Method}

The deep percolation losses of irrigation water which increases water table differs according to irrigation system as shown in Table 2 . 
Table 2, Estimated Deep Percolation as Related to Irrigation Method

\begin{tabular}{|l|c|c|c|c|c|c|c|}
\hline \multirow{2}{*}{$\begin{array}{l}\text { Irrigation } \\
\text { Method }\end{array}$} & Furrow & Border & Basin & Periodic move & Continuous move & Solid set \\
\hline L (\%) & $5-25$ & $10-20$ & $5-20$ & $15-25$ & $10-15$ & $5-20$ & $5-10$ \\
\hline
\end{tabular}

In this study, deep percolation losses $(\mathrm{L})=17.5 \%$ for surface irrigation, $12.5 \%$ for sprinkler irrigation and $7.5 \%$ for trickle irrigation are taken.

\subsubsection{Water logging Time}

The present is carried out using surface irrigation apparatus, hydraulics laboratory, Faculty of Engineering, Zagazig University. By using this apparatus, the time of water-logging for three types of soil is measured experimentally with depth of water is equal to losses of each crop and different irrigation system. The calculation of consumptive use of different crops and losses as deep percolation according to irrigation system and time of water-logging according to soil type are shown in Table 3.

Table 3, Consumptive Use of Different Crops and Time of Water-logging according to Soil Type and Irrigation System

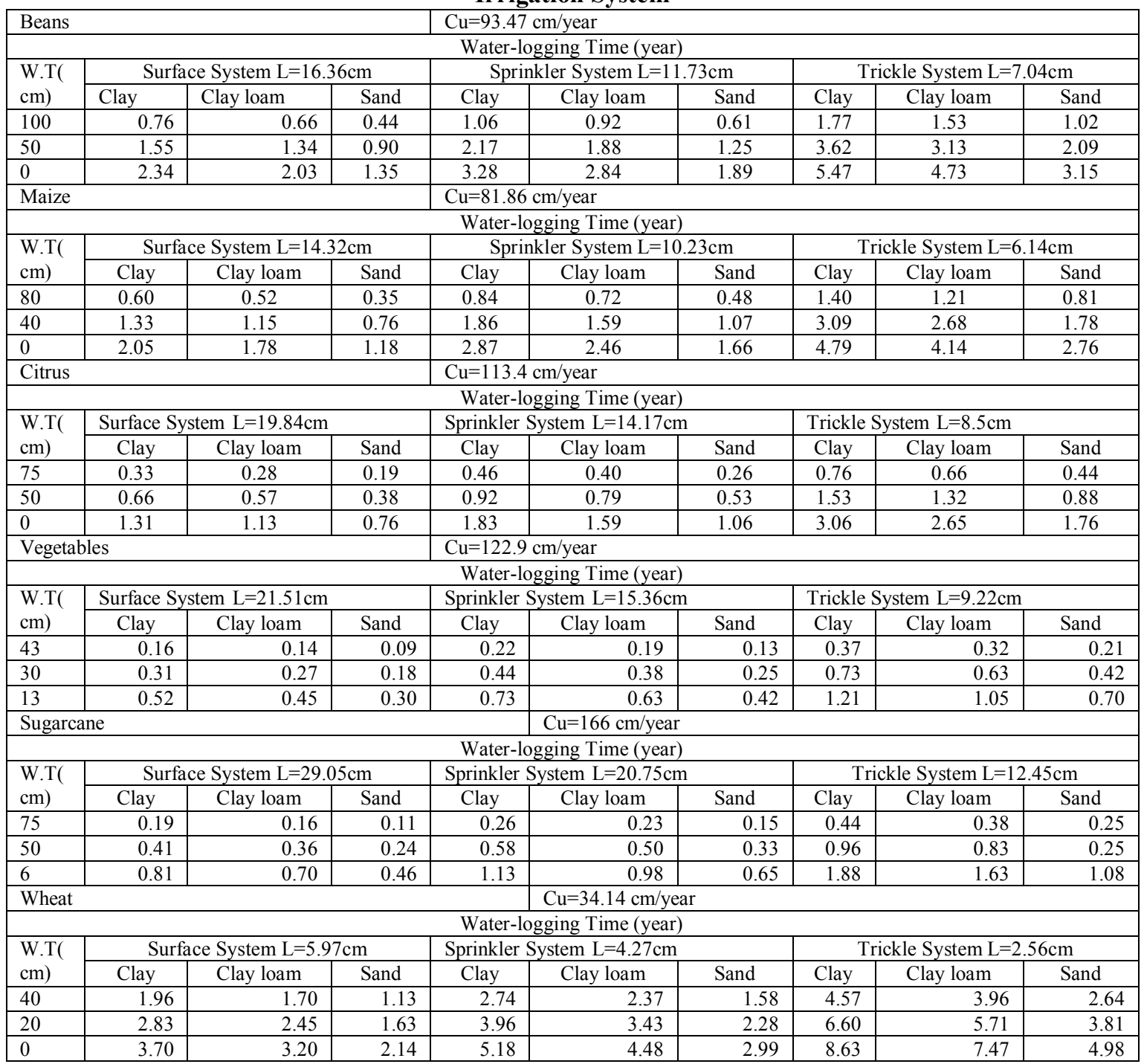

In this study the max depth of water table is taken for each crop as the water depth which achieves max yield and the time of water logging is calculated for each increasing of this datum to soil surface for each crop.

\section{Impact Of Soil Salinity}


Areas of low productivity over several seasons and land uses are classified as likely to be salt-affected if they are in water accumulating parts of the landscape and provide similar spectral signatures as known areas of salinized land. A soil salinity problem exists when the buildup of salts in a crops root zone is significant enough that a loss in crop yield. Crops are generally unaffected by salinity up to a threshold at which time yield will begin to decrease linearly as soil salinity levels increase. This type of two-piece linear relationship between relative crop yield $\left(\mathrm{Y}_{\mathrm{S}}\right)$ and the electrical conductivity of the soil extract $\mathrm{EC}(\mathrm{mmhos} / \mathrm{cm})$ can be described mathematically as follows [23]:

$Y_{s}=100-b(E C-a)$ for $E C \geq a$

Where,

b: The slope of the yield response to salinity;

a: The salinity threshold level at which crop yields begin to be affected.

The thresholds and slope parameters are used in this study to reflect the responsiveness of the relevant crops to salinity stressing as shown in Table 4 .

Table 4, Soil Salinity Ratings, Thresholds, and Slope Response Parameters

\begin{tabular}{|l|l|l|}
\hline Crop & Threshold (a) & Slope (b) \\
\hline Beans & 1.0 & 19.0 \\
\hline Maize & 1.7 & 12.0 \\
\hline Citrus & 1.0 & 8.4 \\
\hline Vegetables & 1.0 & 8.0 \\
\hline Sugarcane & 6.8 & 16 \\
\hline Wheat & 6.0 & 7.1 \\
\hline
\end{tabular}

\section{Combined Effects Of Both Water-Logging And Soil Salinity}

Interactions between salinity and water logging can have a major impact on plant growth and survival because there is a synergetic effect. Water logging may be a serious inhibitor for plant growth even at low levels of salt. This can be significant for rehabilitation because it is often easier to reduce water logging intensity (with shallow drainage) than manage salinization. Plants that are water-logged are very susceptible to salinity, especially in their early growth stages. Under saline conditions this inhibits the ability of roots to screen out salt during water uptake which allows lethal concentrations of salt to occur in the plant shoots. It is not unexpected, therefore, that the lowest uptake of salt occurs for plants with a tolerance to water logging. The effects of soil salinity on crop production are increased when water logging conditions are present. The relation of the total relative yield factor $\left(\mathrm{Y}_{t}\right)$ for each crop to be the product of the relative yield associated with soil salinity $\left(\mathrm{Y}_{\mathrm{s}}\right)$ and the relative yield associated with water logging $\left(\mathrm{Y}_{\mathrm{WTD}}\right)$ as follows [23]:

$\mathrm{Y}_{\mathrm{t}}=\mathrm{Y}_{\mathrm{s}} * \mathrm{Y}_{\mathrm{WTD}}$

\section{Extent Of The Problem In Egypt}

Water-logging problem appeared in many places in Egypt. This problem is appeared in El-Salhia, ElSarkia governorate, Egypt. The reason of water-logging in El-Salhiya is due to surface irrigation or seepage from El-Salhiya Canal or sand removing or drainage system is not found or rice cultivating or all of these reasons. Water-logging is being a big problem in El-Salhiya, because the area of water-logging is 7000 feddans approximately.

\subsection{Area and Location}

El-Salhiya is located eastern edge of Sharkiya Governorate, as shown in Fig 1. Fakous city is in north of El-Salhiya, Abou Hamad city is in west of El-Salhiya, and Ismailya Governorate is in the east and south of El-Salhiya. The area of El-Salhiya is 120,000 feddans.

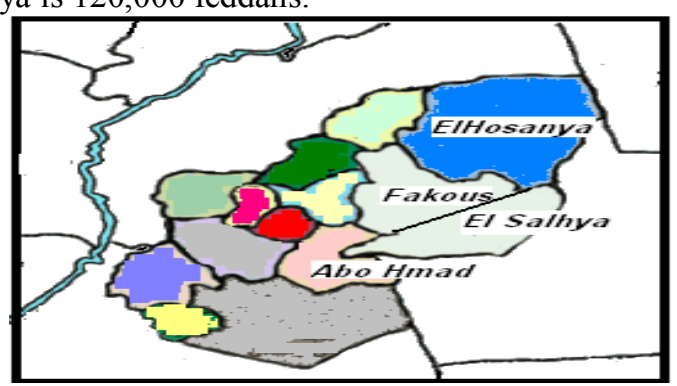

Fig1. Location of the Case Study

\subsection{Soil Texture}

The soil texture in this area is fine sand varies from $172 \mathrm{~m}$ depth in east, to $180 \mathrm{~m}$ in south east.

\subsection{Crop Pattern}


The crop pattern in El-Salhiya is $45 \%$ citrus (along the year), 35\% vegetables (along the year), $10 \%$ wheat (about 4months), and 10\% maize (about 7 months).

\subsection{Calculation of Water-logging Time}

The max depth of water table is taken the largest depth of water table which is suitable for the four crops which is cultivated in El-Salhia and achieves max yield (113 cm from soil surface for maize), the water-table time is calculated for sand soil and each increasing in water table according to the four crops by their percentage, for example, calculation of water-logging time for increasing the water depth according to maize only from $113 \mathrm{~cm}$ to $100 \mathrm{~cm}$ from the soil surface, then calculation of water-logging time for increasing the water depth according to maize and citrus from $100 \mathrm{~cm}$ to $85 \mathrm{~cm}$ from the soil surface, etc.

The consumptive use of the four crops which are cultivated in El-Salhia is calculated by using BlaneyCriddle. The consumptive use and the losses which increase the water table rise due to three irrigation system are shown in Table 5.

Table 5, The Consumptive Use and Losses in El-Salhia

\begin{tabular}{|l|c|c|c|c|c|}
\hline Crop & Percentage (\%) & \multirow{2}{*}{ Cu(cm/year) } & \multicolumn{3}{|c|}{ Losses (cm/year) } \\
\cline { 3 - 6 } & & & Surface & Sprinkler & Trickle \\
\hline Maize & 10 & 81.86 & 14.32 & 10.23 & 6.14 \\
\hline Citrus & 45 & 34.14 & 5.97 & 4.27 & 2.56 \\
\hline Vegetables & 35 & 122.90 & 21.51 & 15.36 & 9.22 \\
\hline Wheat & 10 & 113.40 & 19.84 & 14.17 & \\
\hline
\end{tabular}

\subsection{Effect of Combined Water-logging and Salinity}

The effect of water-logging only on the crop yields is estimated, the effect of salinity only on the crop yields is estimated also, and then the combined effect of them on the crop yields in El-Salhia is calculated for the four crops by using equation 5 .

\subsection{Net Profit}

By using equation 1, using the percentage of crop yields estimated under the both effect of water-logging and salinity, and the water quantity for consumptive use and leaching, the net profit is calculated. The crop yield per feddan, the price of each product, the cost of production per feddan, the volumes of water used for irrigation and leaching are shown in Table 6 , the price of water $\left(\mathrm{P}_{\mathrm{w}}\right)$ is taken $=0.15 \mathrm{LE}$.

Table 6, The Yield of Crop, Product Price \& Cost, Irrigation \& Leaching Water Volumes

\begin{tabular}{|l|c|c|c|c|r|}
\hline Crop & Yield/fed. & Price of Product $(\mathrm{LE})$ & $\mathrm{H}_{\mathrm{k}}(\mathrm{LE})$ & $\mathrm{V}_{\mathrm{r}}\left(\mathrm{m}^{3} / \mathrm{fed}.\right)$ & $\mathrm{V}_{\mathrm{L}}\left(\mathrm{m}^{3} / \mathrm{fed}\right)$ \\
\hline Maize & $28 \mathrm{ardab}$ & 330 & 350 & 3437.96 & 343.8 \\
\hline Citrus & 9 ton & 4200 & 15000 & 4762.70 & 476.27 \\
\hline Vegetables & 8 ton & 3500 & 13000 & 5161.79 & 516.18 \\
\hline Wheat & $20 \mathrm{ardab}$ & 420 & 400 & 1433.82 & 143.38 \\
\hline
\end{tabular}

\section{Results And Discussion}

\subsection{Results of Effect of Water-logging on the Crop Yield}

By application equation (2) it is found that, the max yield of beans is at $1.48 \mathrm{~m}$ from ground surface and it decreases gradually to $71.9 \%$ at completely soil waterlogged, the max yield of maize is at $1.33 \mathrm{~m}$ from ground surface and it decreases gradually to $25.4 \%$ at completely soil waterlogged, the max yield of citrus is at $1.0 \mathrm{~m}$ from ground surface and it decreases gradually to $16 \%$ at completely soil waterlogged, the max yield of vegetables is at $0.56 \mathrm{~m}$ from ground surface and it decreases gradually to $1.1 \%$ at $0.13 \mathrm{~m}$ from surface, the max yield of sugarcane is at $0.96 \mathrm{~m}$ from ground surface and it decreases gradually to $1.0 \%$ at $0.06 \mathrm{~m}$ from surface, and the max yield of wheat is at $0.85 \mathrm{~m}$ from ground surface and it decreases gradually to $69.4 \%$ at completely soil waterlogged, the effect of water table depth and crop yield is shown in Fig. 2. 


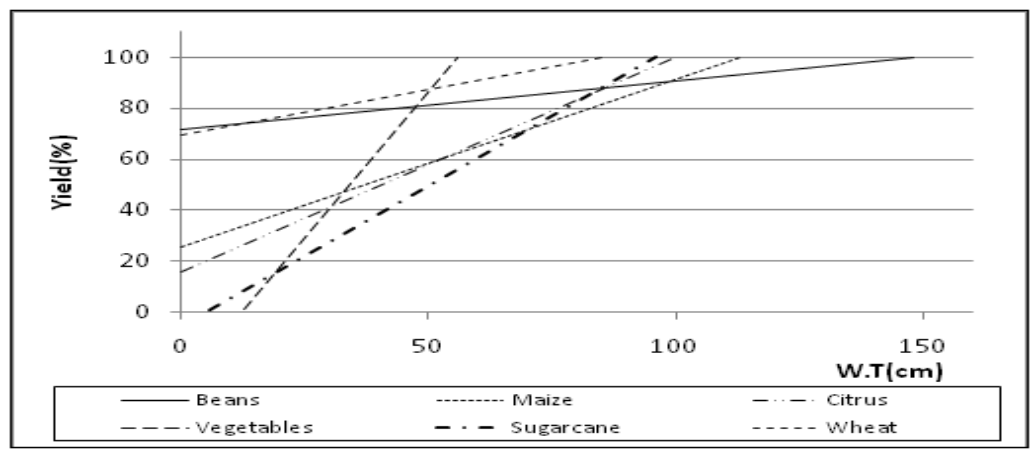

Fig 2. The Effect of Water Table Depth on Crop Yield

\subsection{Results of Effect of Water-logging Duration}

For different crops the time of reaching water table from the datum (the water depth from soil surface which achieve the maximum yield) of each crop to is changing according to the soil type and irrigation method. The relation between the water depth from ground surface and water-logging time for different crops and different soil is shown in Fig 3.
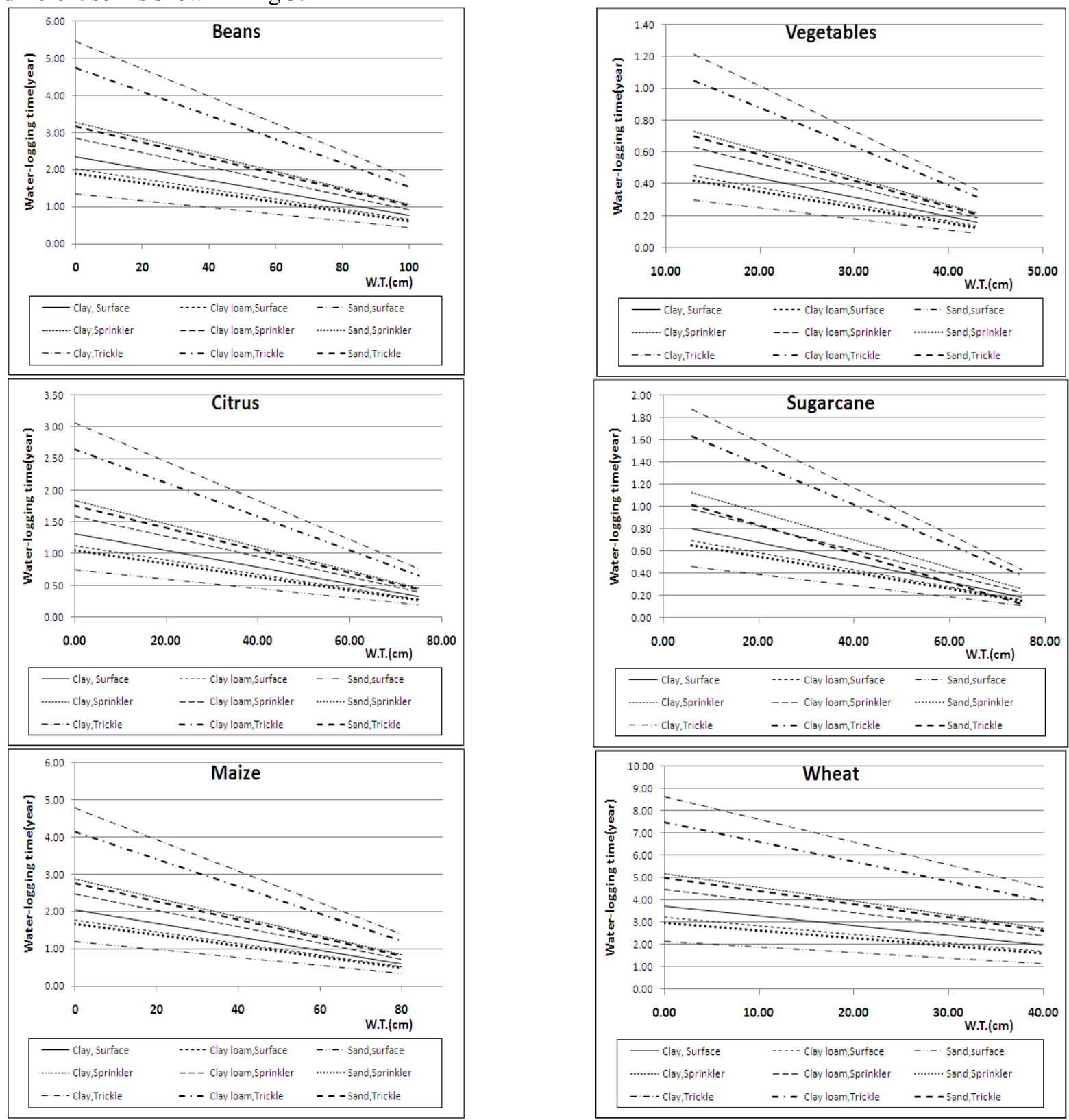

Fig 3. The Relation between Depth of Water Table from Soil Surface and Water logging Time for Different Crops, Soil and Irrigation System 


\subsection{Results of Effect of Salinity on the Crop Yields}

By application of equation (4), it is found that the least yield for beans at salinity (EC) $=6.26 \mathrm{mmhos} / \mathrm{cm}$, for maize at $\mathrm{EC}=10.03 \mathrm{mmhos} / \mathrm{cm}$, for citrus at $\mathrm{EC}=12.9 \mathrm{mmhos} / \mathrm{cm}$, for vegetables at $\mathrm{EC}=13.5 \mathrm{mmhos} / \mathrm{cm}$, for sugarcane at $\mathrm{EC}=13.05 \mathrm{mmhos} / \mathrm{cm}$ and for wheat at $\mathrm{EC}=20.08 \mathrm{mmhos} / \mathrm{cm}$. The effect of soil salinity which expressed in terms of electric conductivity on crop yield is shown in Fig 4.

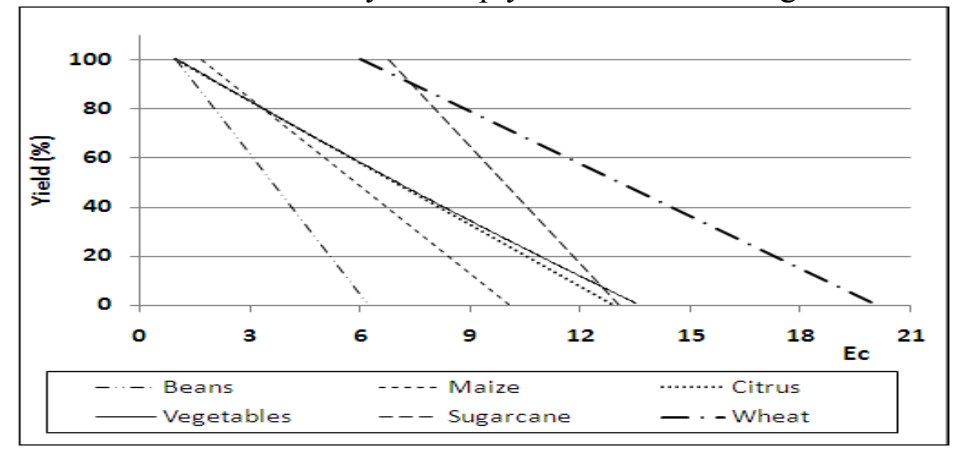

Fig 4: Effect of Soil Salinity on Crop Yield

\subsection{Results of Combined Effect of Water-logging and Salinity on the Crop Yield}

By using equation 5, the effect salinity of on each crop is calculated for each increasing in the water table depth. The combined effect of both water-logging and soil salinity on crops yield is shown in Fig 5.
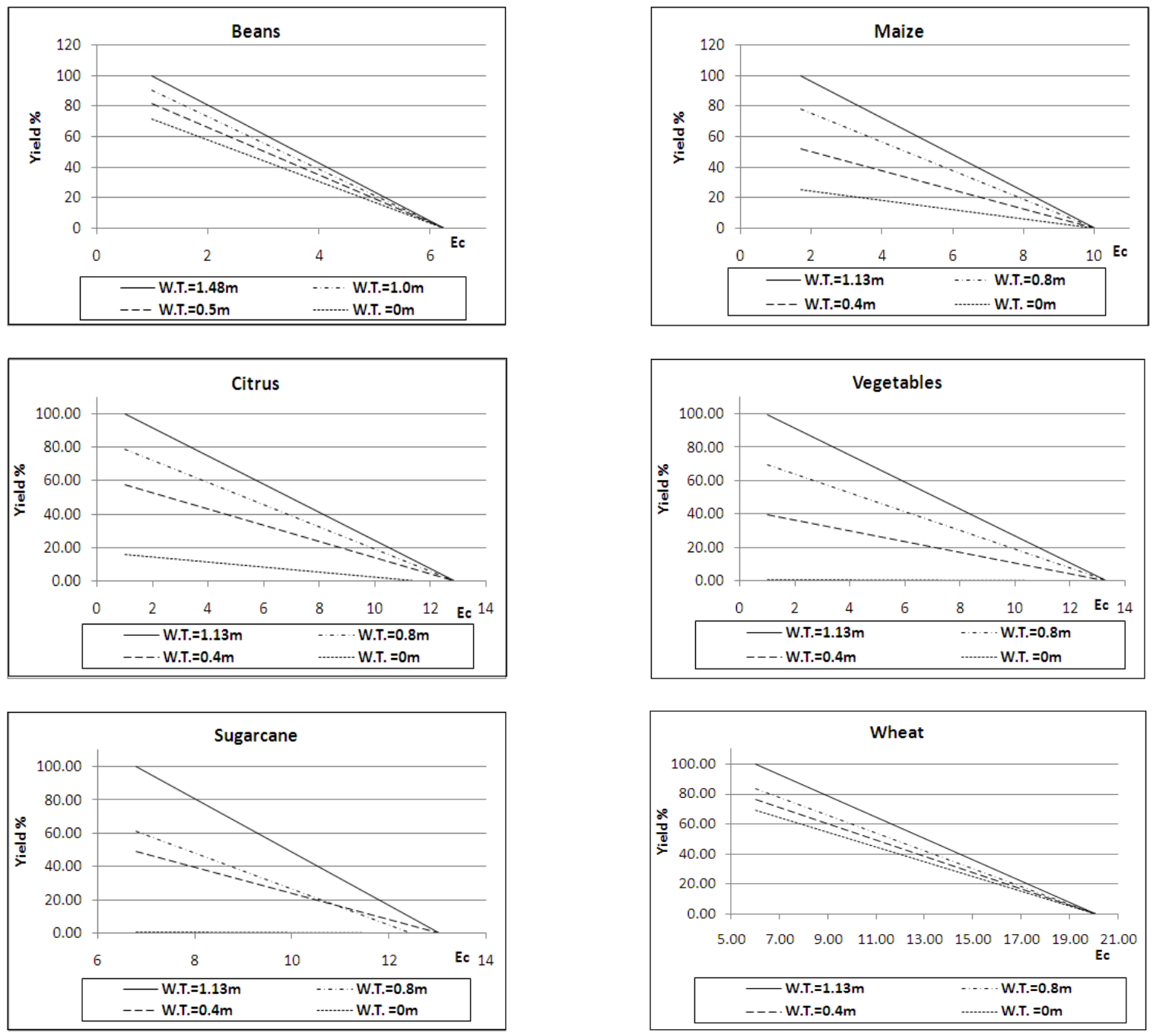
Fig 5. The Combined Effect of both Water-logging and Soil salinity on Crops Yield

\subsection{Results of Combined Effect of Water-logging and Salinity on the Crop Yield in the Case Study}

\subsubsection{Water-logging Duration}

The relation between the water depth from soil surface and water-logging time for the four crops for sand soil and for different irrigation method is shown in Fig 6 .

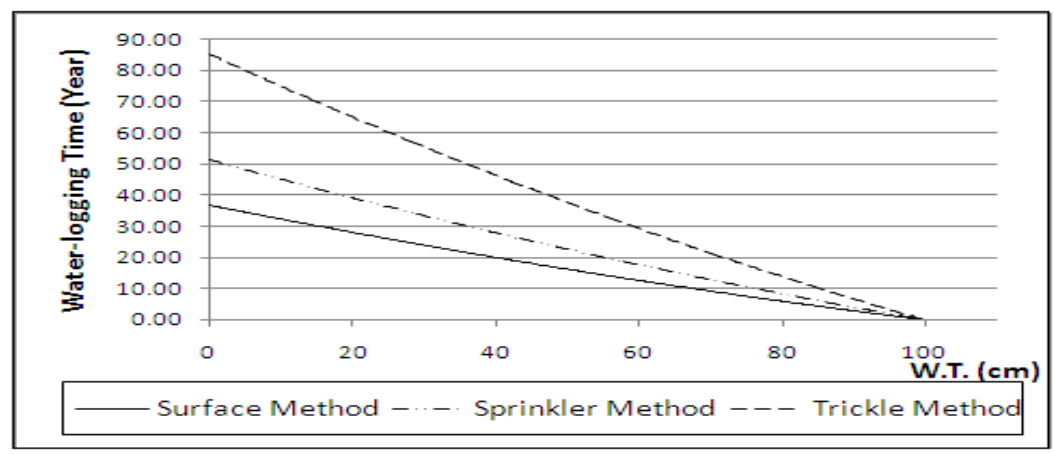

Fig. 6 The Water logging Time according to Water Table Depth for Different Irrigation Method, in ElSalhia

\subsubsection{Combined Effect of Water-logging and Salinity}

The combined effect of both water-logging and soil salinity on the four crops yield in El-Salhia is shown in Fig 7.

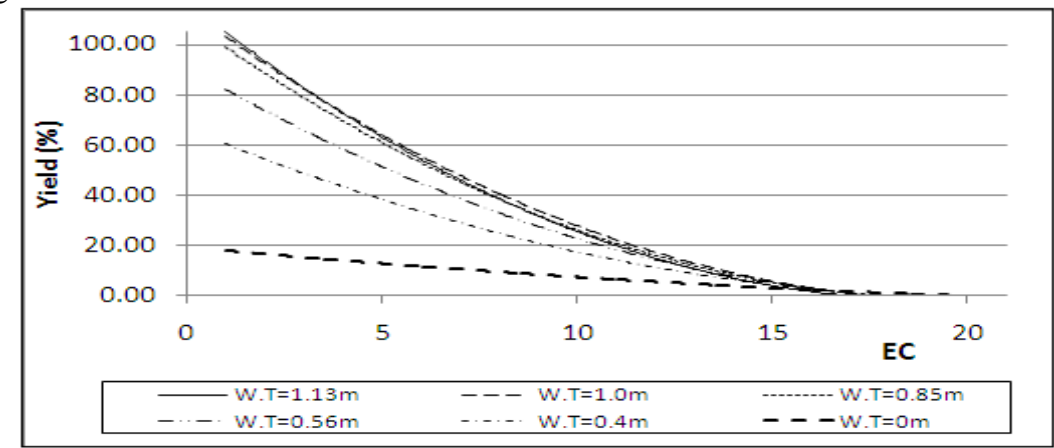

Fig 7. Combined Effect of both Water-logging and Soil Salinity in El-Salhia

\subsubsection{Results of Net Profit}

The distribution of the maximum profit can also be seen graphically for each water table depth and salinity value in Fig 8 .

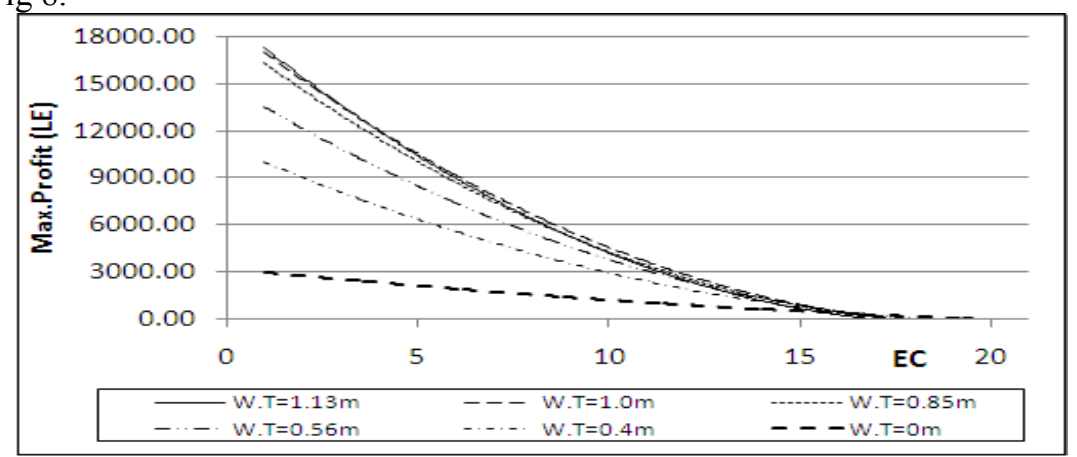

Fig 8. Net Benefit per Faddan for Different Water Table Depth

\section{Conclusions}


Water logging of agricultural lands occurs when there is inadequate oxygen available in the crops root zone as a result of excess water. Reduced oxygen supplies to a crops root as a result of a shallow water table reduces nutrient uptake, crop growth, and yield. In general, when a shallow water tables exists the yields of most crops can be related to the depth of the water table. For most crops there exists an "optimum" water table depth, at which aeration, moisture, and nutrients are such that crop yields can be maximized. When the water table rises above this threshold, crop yields begin to decline.

This article analyzes the risk of water logging and salinity on the crop yields and the net profit. The effect of water logging on crop yields is estimated, the water logging time according the crop consumptive use for different soil types and irrigation method is calculated. The effect of salinity and the combined effect of them on crop yield are estimated also and then this research includes the application in El-Salhia as a case study.

The results of this study indicate that the direct production losses and associated forgone profits as a result of water logging and soil salinization are significantly impacting farmers located within the study area.

[1] Barrett L, Leighton P, Mcpharlin I., Setter T and Greenway H. "Methods to experimentally control water-logging and measure soil oxygen in field trials" Australian Journal of Soil Research, 1986; 24(4): 477 - 483

[2] Wichelns D. "Analysis an economic model of water-logging and salinization in arid Regions" Ecological Economics, 1999; 30:475 $-491$

[3] Kotob T., Watanabe T., Ogino Y., and Tanji K " Soil salinization in the Nile Delta and related policy issues in Egypt" Agricultural Water Management, March 2000; 43(2): 239-261

[4] McFarlane D. and Williamson D. "An overview of water logging and salinity in southwestern Australia as related to the 'Ucarro' experimental catchment" Agricultural Water Management 53, 2002; 5-29

[5] Pereira L., Oweis T. and Zairi A." Irrigation management under water scarcity" Irrigation management under water scarcity, December 2002, 57(3): 175-206

[6] Hatton T., Bartle G., Silberstein R., Salama R., Hodgson G., Ward P., Lambert P. and Williamson D. "Predicting and controlling water logging and groundwater flow in sloping duplex soils in western Australia" Agricultural Water Management, 2002; 53: 57-81

[7] Silberstein R., Bartle G., Salama R., Hatton T., Reggiani P., Hodgson G., and Williamson D., and Lambert P. " Mechanisms and control of water logging and groundwater flow in the 'Ucarro' sub-catchment" Agricultural Water Management, 2002; 53:227-257

[8] Barrett-Lennard E. "The interaction between water-logging and salinity in higher plants: causes, consequences and implications" Plant and Soil, Kluwer Academic Publishers, 2003; 253: 35-54.

[9] Turner N." Sustainable production of crops and pastures under drought in a Mediterranean environment" Ann. appl. Biol. Printed in UK, 2004; 144:139-147

[10] Cornelious B., Chen P., Chen Y., Leon N., Shannon J. and Wang D. "Identification of QTLs underlying water-logging tolerance in soybean" Molecular Breeding, 2005; 16: 103-112

[11] Su-qin H., Yi-yang X., Da-ming L., Pei-yan L., and Mei-ling S. "Risk analysis and management of urban rainstorm water-logging in Tianjin" Journal of Hydrodynamics Ser.B, 2006; 18(5):552-558

[12] Jacob W. "A biotic stress and water scarcity: Identifying and resolving conflicts from plant level to global level" Field Crops Research, 2006; 97: 3-18

[13] Choudhury N. "Irrigation service delivery in canal systems: a study of eight canal systems in India" International Journal of Rural Management, 2007; 3(1): 127-148

[14] Elew, H. and ElNahry A. "Hydro-environmental status and soil management of the River Nile Delta, Egypt" Environmental Geology April, 2009; 57(4):759-774

[15] Prietzel J., Thieme J., and Paterson D. "Phosphorus speciation of forest-soil organic surface layers using P K-edge XANES spectroscopy" J. Plant Nutr. Soil Sci. 2010; 173: 805-807

[16] El-Bastawesy M. and Ali R. "The use of GIS and remote sensing for the assessment of water-logging in the dry land irrigated catchments of Farafra Oasis in Egypt" Hydrol. Earth Syst. Sci. Discuss., 2011; 8:10535-10563.

[17] Guang C., Xiugui W., LIU Y., and Wenbing L. "Effect of water-logging stress on cotton leaf area index and yield" International Conference on Modern Hydraulic Engineering, procedia Engineering, 2012; 28:202-209

[18] Rizvi F. "Irrigation development: A process of land degradation and marginalization of the land poor" Social Change, 2012; 42(1): $31-47$

[19] Magsi H. and Torre A. "Social Network Legitimacy and Property Right Loopholes: Evidences from an Infrastructural Water Project in Pakistan" Journal of Infrastructure Development, India Development foundation SAGE Publications New Delhi, Singapore, Washington DC, 2012; 4(2): 59-76

[20] Badiani R., Jessoe K. and Plant S. "Development and the environment: The implications of agricultural electricity subsidies in India" Journal of Environment \& Development, 2012; 21(2): $244-262$

[21] Xiugui W., Lin W., Guang C., LIU Y. " Experimental study on dynamics crop model under water-logging Stress" International Conference on Modern Hydraulic Engineering, procedia Engineering, 2012; 28: 866-872

[22] Saqib M., Akhtar J., Qureshi R., and Nasim M. "Selection and characterization of wheat genotypes for saline soils prone to waterlogging" J. Plant Nutr. Soil Sci., 2013; 000: 1-7

[23] Houk E., FrasierM., Schuck E. "The Regional Effects Of Water-logging And Soil Salinization On A Rural County In The Arkansas River Basin Of Colorado" Selected paper presented for presentation at the Western Agricultural Economics Association, 2004

[24] Sammis T., Wang J. Miller D. "The Transition of the Blaney-Criddle Formula to the Penman-Monteith Equation in the Western United States" Journal Of Service Climatology, 2001; 5(1):1-11 